\title{
METABOLIC STUDIES IN LOUSE-BORNE TYPHUS. OBSERVATIONS ON SERUM ELECTROLYTE PATTERN, SERUM PROTEIN PARTITION, AND NITROGEN BALANCE
}

\author{
By NICHOLAS A. TIERNEY 1 AND ANDREW YEOMANS 2 \\ (From the Cairo Unit of the United States of America Typhus Commission, \\ War Department, Washington, D. C.)
}

(Received for publication May 20, 1946)

Although a great deal has been written about the clinical aspects of louse-borne typhus, there have been only a few reports on the metabolic changes which occur in this disease. Among the first biochemical studies on typhus were those reported by Murchison (1) in 1862. He discovered that large amounts of urea frequently were present in the blood of typhus patients, and that their urine contained abnormally large amounts of nitrogen. He attributed this to an "exaggerated disintegration of nitrogenous tissues." Since then other physicians have postulated excessive protein destruction in association with elevated blood and urine nitrogen $(2,3)$.

Renewed interest in this problem was aroused by recent studies (4) which showed that azotemia, or nitrogen retention, was a common finding in louse-borne typhus, and in general related to the severity of the case. In these studies it was reported that azotemia was present in every fatal case.

Little is known about the general electrolyte pattern in typhus. Murchison (1) noted that the chlorides were greatly reduced in the urine. He believed that this was due either to an impairment of absorption of chlorides or to their absolute retention. Since then other investigators have reported low chlorides in the blood of typhus patients (5). Julliard and Henaff (6) reported the serum and urine chlorides low until 1 week after defervescence. Woodward and Bland (3) reported the serum chlorides low and the carbon dioxide combining power high. They believed that a state of alkalosis existed in several of the patients, and suggested the use of ammonium chloride in the therapy. These workers also reported that often there was a reversal in the albuminglobulin ratio.

\footnotetext{
1 Lieutenant, (MC) USNR.

2 Commander, (MC) USNR.
}

It appeared that a better knowledge of the electrolytes in this disease was essential for good supportive treatment. Consequently, studies were carried out on the salt intake and output and on the more prominent acid and basic radicals in the serum, including the proteins.

Because of the great protein destruction, it seemed important to know how much nitrogen was being excreted in the urine and what bearing it could have on the azotemia. It also seemed important to spare by dietary measures as much of the body protein as possible, therefore, studies were conducted along these lines.

Selection of patients. The patients in this study were unvaccinated Egyptian males between the ages of 12 and 48 years. The majority of these patients were thin and some of them were undernourished, but in no instances was avitaminosis observed. They were admitted to the United States of American Typhus Commission (7) ward in 1944-45 during the first 2 weeks of their disease. The diagnosis of louse-borne typhus was confirmed in all of these cases by the Weil-Felix and complement-fixation tests. $^{3}$ When patients received para-aminobenzoic acid (8) it is noted in the tables.

Estimation of severity of illness. After discharge from the hospital, each patient was classified according to the severity of his illness. This classification was based on the severity of the signs and symptoms, the duration of the disease and the occurrence of complicating conditions. With these factors in mind the following classifications were made:

"B"-Cases with minimal signs and symptoms, yet definitely diagnosed as typhus on clinical evidence.

"C"-Cases of moderate severity.

"D"-Severe cases with pronounced prostration.

"E"-Cases so severe that a fatal outcome was suspected at some point in the disease.

"F"-Fatal cases.

Methods. For the determination of carbon dioxide, chlorides, $\mathrm{pH}$ and total base, venous blood was collected

3 Grateful appreciation is expressed to Major C. J. D. Zarafonetis and Sgt. J. Dworkowitz for the performance of the serological tests. 
in oiled syringes without stasis, and placed under oil in centrifuge tubes. As soon as the blood clotted the tubes were stoppered and the excess oil removed. The serum was separated by centrifuging and transferred without delay to sampling bulbs containing mercury.

The carbon dioxide content of the serum was determined in a manometric Van Slyke apparatus. The chlorides were determined by a micro-modification of the open Carius method (9) and the $\mathrm{pH}$ in a Beckman $\mathrm{pH}$ meter. Analyses for total base were carried out by the benzidine method (9). The blood non-protein nitrogen was determined on oxalated specimens by the Nesslerization method (9).

The serum proteins were determined by the macroKjeldahl method (9).

The urine and feces were analyzed for nitrogen by the macro-Kjeldahl method. Twenty-four urine specimens preserved with thymol were analyzed daily. The feces were collected in glass jars containing sulfuric acid as a preservative. Combined collections over a period of 5 to 7 days were thoroughly mixed with water and analyzed. The daily fecal nitrogen was determined by dividing the total fecal nitrogen by the number of days. All analyses were performed in duplicate, and were repeated if the duplicates did not check.

Diets. Liquid diets were given to all of the patients. Some of the patients received a low protein, low caloric diet, while others received a high protein, high caloric diet. The low protein, low caloric diet was prepared to approximate the diet of the patients on the 3rd class hospital wards. A day's intake on this diet contained 6 grams of nitrogen, 1,800 calories and added salt. It was prepared with evaporated milk, corn syrup, sodium chloride and orange juice. The daily high protein, high caloric diet contained 3,400 calories, 21 grams of nitrogen and sodium chloride. It was prepared in a Waring blender with 1 liter of evaporated milk, 10 eggs, 35 grams of casein, $450 \mathrm{ml}$. of corn syrup, salt, water and flavoring. These diets were prepared under the supervision of a medical officer, and were analyzed frequently for nitrogen by the macro-Kjeldahl method. The "salt-free" diet was a low protein diet without added salt. It contained approximately 0.8 gram of sodium chloride, the amount of salt naturally occurring in $550 \mathrm{ml}$. of evaporated milk, and $500 \mathrm{ml}$. of orange juice. If the patient vomited he was excluded from the study.

\section{ELECTROLYTE PATTERN}

Results. Analyses of the carbon dioxide content and the chlorides of the serum in 34 cases revealed frequent abnormalities. In the first 2 weeks of disease the serum chlorides were low in 62 per cent of the cases, but only in 4 cases was the serum carbon dioxide content appreciably low. These results are shown in Tables I and II. There were no abnormally high chloride values except when the patients ingested sodium chloride, and only in one instance, Case 1031, was the serum carbon dioxide content elevated.

The $\mathrm{pH}$ was determined on most of the serum specimens concurrently with the chlorides and carbon dioxide. It was normal in all of the cases except patient 1098, who developed renal failure with marked azotemia and died on the 12th day of disease. On the day of death the serum $\mathrm{pH}$ was 7.20. At that time the non-protein nitrogen was $175 \mathrm{mgm}$. per cent, the carbon dioxide content

TABLE I

Data on the chlorides and carbon dioxide content of the serum in patients on "salt free" diets *

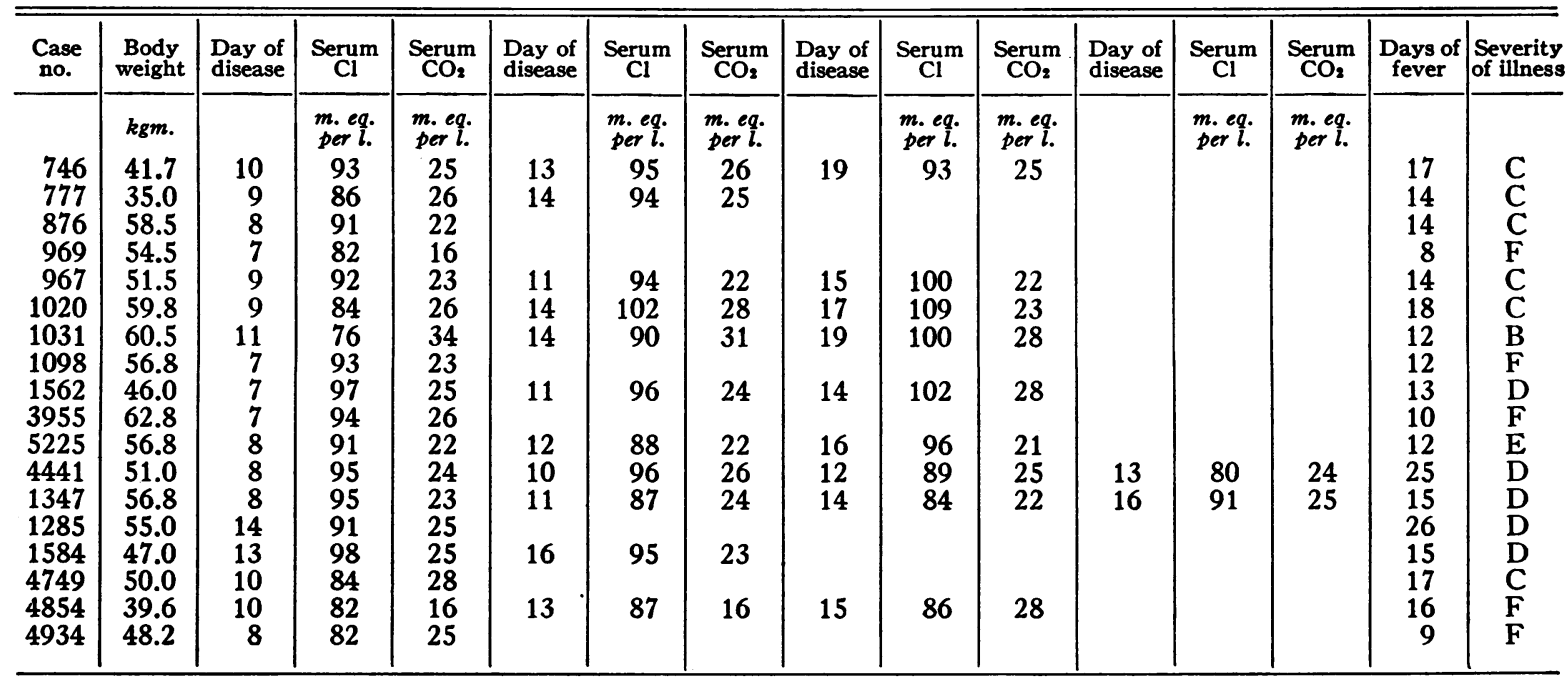

* The salt content of a day's supply of the salt free diet contained approximately 0.8 grams of sodium chloride. 


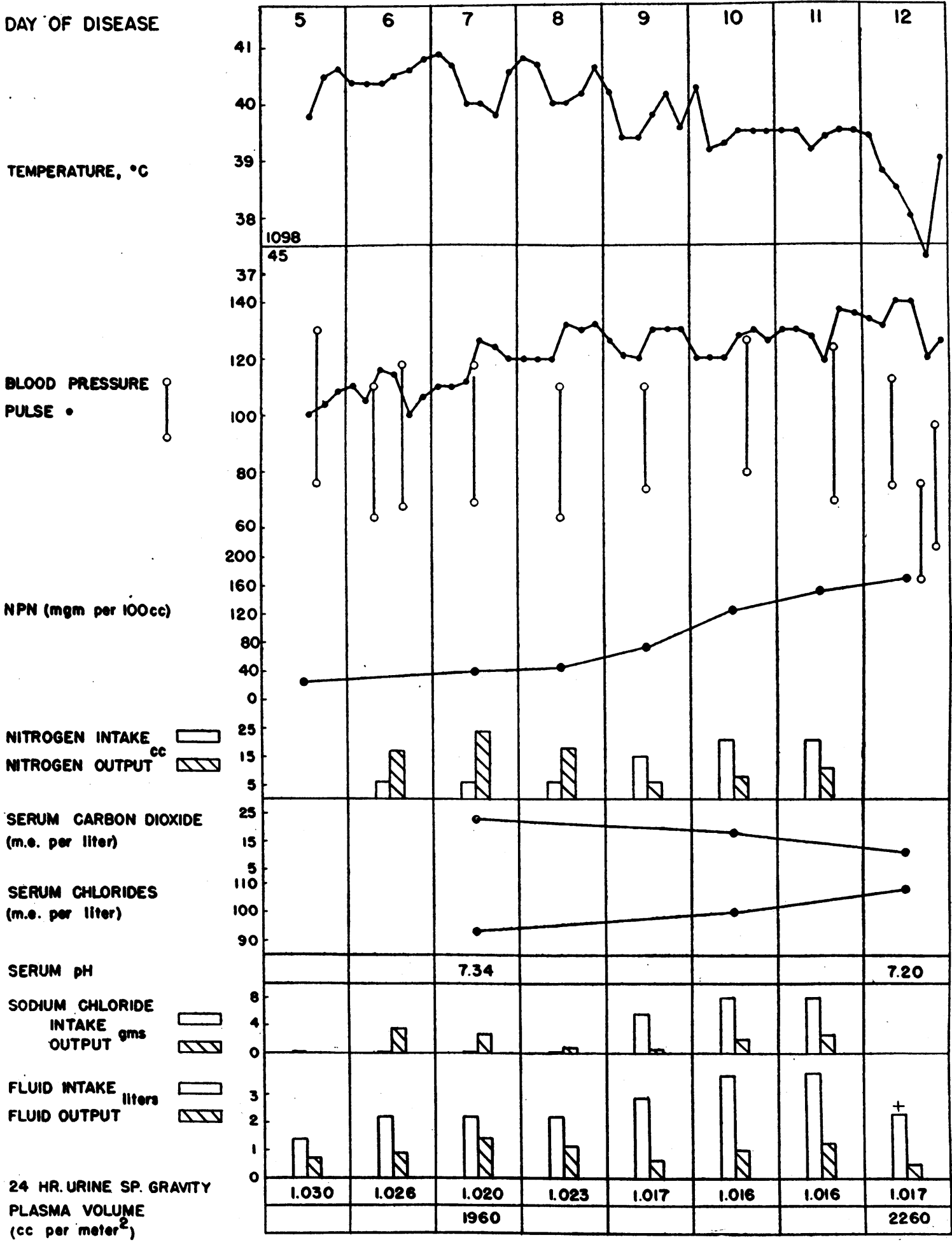

Fig. 1. The Case of a 45-Year Old Male Who Entered the Hospital on the 5th Day of Disease

A rash was not present on admission but became profuse after the 6th day. In the absence of hypotension and with a normal plasma volume* and a daily urine output $\dagger$ of nearly one liter, he developed renal insufficiency. 
TABLE II

Data on the chlorides and carbon dioxide content of the serum in patients receiving added salt in their diets

\begin{tabular}{|c|c|c|c|c|c|c|c|c|c|c|c|c|c|c|c|c|c|}
\hline \multirow{2}{*}{$\begin{array}{l}\text { Case } \\
\text { no. }\end{array}$} & \multirow{2}{*}{$\begin{array}{c}\text { Body } \\
\text { weight }\end{array}$} & \multirow{2}{*}{$\begin{array}{c}\text { Aver- } \\
\text { age } \\
\text { daily } \\
\text { NaCl } \\
\text { intake }\end{array}$} & \multirow{2}{*}{$\begin{array}{c}\text { Aver- } \\
\text { age } \\
\text { daily } \\
\mathrm{NaCl} \\
\text { output }\end{array}$} & $\begin{array}{l}\text { Day of } \\
\text { disease }\end{array}$ & $\underset{\mathrm{Cl}}{\text { Serum }}$ & $\begin{array}{c}\text { Serum } \\
\mathrm{CO}_{2}\end{array}$ & \begin{tabular}{|} 
Day of \\
disease
\end{tabular} & $\underset{\mathrm{Cl}}{\text { Serum }}$ & $\underset{\mathrm{CO}_{2}}{\text { Serum }}$ & $\begin{array}{l}\text { Day of } \\
\text { disease }\end{array} \mid$ & $\underset{\mathrm{Cl}}{\text { Serum }}$ & $\begin{array}{c}\text { Serum } \\
\mathrm{CO}_{2}\end{array}$ & $\begin{array}{l}\text { Day. of } \\
\text { disease }\end{array}$ & $\underset{\mathrm{Cl}}{\text { Serum }}$ & $\underset{\mathrm{CO}_{2}}{\text { Serum }}$ & \multirow{2}{*}{$\begin{array}{l}\text { Days } \\
\text { of } \\
\text { fever }\end{array}$} & \multirow{2}{*}{$\begin{array}{c}\text { Se- } \\
\text { verity } \\
\text { of } \\
\text { case }\end{array}$} \\
\hline & & & & \multicolumn{3}{|c|}{ Before $\mathrm{NaCl}$} & \multicolumn{3}{|c|}{ After $\mathrm{NaCl}$} & \multicolumn{3}{|c|}{ After $\mathrm{NaCl}$} & \multicolumn{3}{|c|}{ After $\mathrm{NaCl}$} & & \\
\hline & kgm. & grams & grams & & \multicolumn{2}{|c|}{ m. eq. per $l$. } & & \multicolumn{2}{|c|}{ m. eq. per $l$. } & & \multicolumn{2}{|c|}{ m. eq. per $l$. } & & \multicolumn{2}{|c|}{ m. eq. per $l$. } & & \\
\hline 446 & 58.3 & 11.5 & 11.0 & 9 & 88 & 24 & 13 & 103 & 22 & 15 & 108 & & 20 & 126 & 24 & 20 & $\mathrm{E}$ \\
\hline 3284 & 55.7 & 10.5 & 10.7 & 8 & 102 & 24 & 13 & 112 & 23 & & & & & & & 17 & C \\
\hline 2501 & 54.5 & 9.5 & 4.0 & 3 & 96 & 25 & 13 & 107 & 23 & & & & & & & 31 & $\mathbf{E}$ \\
\hline 3009 & 40.0 & 9.5 & 6.6 & 7 & 95 & 23 & 15 & 109 & 23 & & & & & & & 16 & C \\
\hline 1174 & 54.5 & 9.5 & 8.2 & 9 & 97 & 24 & 15 & 104 & 25 & & & & & & & 10 & B \\
\hline 1332 & 46.3 & 9.5 & .6 & 6 & 85 & 20 & 9 & 103 & 20 & & & & & & & 11 & $F$ \\
\hline 447 & 51.3 & 8.5 & 6.5 & 9 & 87 & 26 & 11 & 96 & 25 & 16 & 97. & 26 & & & & 16 & $\mathbf{F}$ \\
\hline 666 & 46.0 & 8.5 & 1.6 & 8 & 96 & 21 & 12 & 114 & & & & & & & & & C \\
\hline 1105 & 41.5 & 8.5 & 11.7 & 8 & 93 & 23 & 12 & 97 & 23 & 17 & 91 & 23 & & & & 18 & D \\
\hline 1014 & - & 9.5 & 6.5 & 10 & 88 & 31 & 16 & 98 & 23 & 19 & 101 & 26 & & & & 18 & D \\
\hline 1499 & 61.8 & 5.0 & 1.4 & 7 & 93 & 23 & 14 & 113 & 16 & & & & & & & & D \\
\hline $\begin{array}{l}4246 \\
1600\end{array}$ & 48.7 & 6.5 & $\begin{array}{l}7.4 \\
62\end{array}$ & 8 & 98 & 23 & 10 & $\begin{array}{r}98 \\
100\end{array}$ & 25 & & & & & & & 12 & $\mathrm{~F}$ \\
\hline $\begin{array}{r}1609 \\
876\end{array}$ & $\begin{array}{l}01.7 \\
58.5\end{array}$ & $\begin{array}{l}7.0 \\
4.0\end{array}$ & $\begin{array}{l}0.2 \\
5.1\end{array}$ & 8 & 91 & 22 & $\begin{array}{l}12 \\
12\end{array}$ & $\begin{array}{r}100 \\
98\end{array}$ & 22 & 15 & 96 & 25 & & & & 14 & C \\
\hline 1178 & 56.0 & 6.5 & $\begin{array}{r}.8 \\
.8\end{array}$ & 10 & 87 & 22 & 14 & 99 & 26 & & & & & & & & $\mathbf{F}$ \\
\hline 1845 & 54.0 & 6.5 & 1.3 & 9 & 96 & 23 & 13 & 102 & 25 & & & & & & & 14 & C \\
\hline
\end{tabular}

11.6 m.eq. per liter, and the chlorides 108 m.eq. per liter. As this patient presented such interesting electrolyte changes, a detailed chart of his hospital course is shown in Figure 1.

It was generally the rule that when the serum chlorides were low the urine chlorides were either absent or greatly decreased. Case No. 4441 (Table I) was the only exception. This patient, in spite of low serum chlorides, continued to waste salt in his urine. When his serum chlorides were 80 m.eq. per liter, he excreted 4 grams of salt in a 24 hour collection of urine.

Eighteen patients were given "salt free" diets, and more than one determination of serum chlorides and carbon dioxide content was performed on 11 of them. It was noted in 5 cases that the chlorides rose during the 2 nd or 3 rd weeks of the disease despite the "salt free" diet. In 2 cases they fell, and in 4 cases they remained essentially unchanged. This is shown in Table I.

The addition of salt to the diet of the patients caused the serum chlorides to rise higher and more abruptly in the preceding cases (Table II). In a number of instances, the addition of 7 to 10 grams of sodium chloride to the daily diet with a natural salt content of no more than 1.5 grams effected abnormally high serum chlorides. This happened in cases 446, 3284, 3009 and 666 in Table II. Three of these patients continued to excrete most of the ingested salt, and yet the serum chlorides rose to abnormally high levels. This rise in the serum chlorides could not be accounted for by the difference in the salt intake and output. By including 4 to 7 grams of sodium chloride in the daily diet the serum chlorides were maintained within the normal range except in one case, and a good state of hydration was achieved. Patient 1499 who developed high serum chlorides on a daily intake of 4 grams of salt had renal failure. A summary of the effect of added salt on the serum chlorides is presented in Table II.

In a great many cases the sum of the carbon dioxide content and the chlorides of the serum was low. For that reason the total base was deter-

This was manifested by azotemia, a reduction in the 24-hour urine specific gravity and acidosis. The plasma volume was determined on the 12th day, and immediately after this the patient was given 1,400 ml. of isotonic human albumin intravenously in association with studies on the renal plasma flow. Seven hundred ml. of 10 per cent dextrose were given later in the day, and because of the severe degree of acidosis and accompanying dyspnea, $500 \mathrm{ml}$. of 10 per cent dextrose containing 25 grams of sodium bicarbonate were administered intravenously, but with no apparent effect. The patient died on the 12th day of disease.

* The plasma volume determination in this patient was performed by Comdr. R. A. Phillips, MC, USNR, using the blue dye (T-1824) method.

$\dagger$ The fluid output in all of these charts means urine output. 
mined on several of these specimens. Serum proteins including albumin and globulin were determined in all cases. The results of these balance studies on 15 patients are shown in Table III.

The total base was normal in all cases except 5951, but this patient was receiving sodium bicarbonate. Serum calcium and phosphorus determinations were made in 10 cases. The values obtained were normal in all instances except one in which the calcium was slightly low. When the sum of the equivalents of carbon dioxide, chlorides, albuminates and globulinates was subtracted from the total base, an abnormally high value frequently was obtained for undetermined acids.

In view of the absence of severe azotemia in these cases, with the exception of case 4854 , reten- tion of the normal inorganic anions, $=\mathrm{HPO}_{4}$ and $=\mathrm{SO}_{4}$, is unlikely and it would appear that the increase in undetermined acids must have been largely organic. Studies to determine the exact nature of this undetermined acid were not made, however.

Comment. The low serum chlorides in the early stage of typhus require an explanation. It is likely that the diets of these patients before hospitalization were poor in salt. This change was not conspicuous, however, at corresponding stages in diseases other than typhus which were admitted to the Commission ward, e.g., relapsing fever and typhoid. Perspiration was not a factor, as it rarely was observed in these typhus patients. This phenomenon was not peculiar to the dry climate

TABLE III

Acid-base balance studies of the serum in 15 typhus patients

\begin{tabular}{|c|c|c|c|c|c|c|c|c|c|c|c|c|}
\hline Case no. & Age & $\begin{array}{l}\text { Day of } \\
\text { disease }\end{array}$ & $\begin{array}{c}\text { Severity } \\
\text { of case }\end{array}$ & $\begin{array}{c}\mathrm{CO}_{2} \\
\text { content } \\
(1)\end{array}$ & $\begin{array}{l}\mathrm{Cl} \\
\text { (2) }\end{array}$ & $\begin{array}{l}\text { Alb./ } \\
\text { Glob. }\end{array}$ & $\begin{array}{c}\text { Albumi- } \\
\text { nate } \\
(3)\end{array}$ & $\begin{array}{c}\text { Globuli- } \\
\text { nate } \\
(4)\end{array}$ & $\begin{array}{l}\text { Total } \\
\text { base }\end{array}$ & NPN & $\mathrm{pH}$ & $\begin{array}{c}\text { Undeter- } \\
\text { mined acid } \\
\text { (total base } \\
\text { minus } \\
1+2+3+4)\end{array}$ \\
\hline 1332 & 35 & 7 & F & $\begin{array}{l}\text { m. eq. } \\
\text { per } l \text {. } \\
19.8\end{array}$ & $\begin{array}{l}\text { m. eq. } \\
\text { per l. } \\
84.7\end{array}$ & $\begin{array}{c}\begin{array}{c}\text { grams per } \\
100 \text { ml. } \\
2.17\end{array} \\
\frac{3.33}{}\end{array}$ & $\begin{array}{c}\text { m.eq. } \\
\text { per l. } \\
5.95\end{array}$ & $\begin{array}{c}\text { m.eq. } \\
\text { per l. } \\
6.23\end{array}$ & $\begin{array}{l}\text { m. eq. } \\
\text { per l. } \\
143.4\end{array}$ & $\begin{array}{c}\text { mgm. per } \\
100 \text { ml. } \\
40\end{array}$ & 7.35 & $\begin{array}{c}m . e q . \\
26.7\end{array}$ \\
\hline 1499 & 23 & 6 & D & 22.7 & 93.3 & $\frac{3.85}{2.43}$ & 10.9 & 4.7 & 138.9 & 35 & 7.42 & 7.3 \\
\hline 1499 & & 13 & & 16.5 & 112.8 & $\frac{4.01}{2.92}$ & 11.3 & 5.5 & 156.3 & 60 & 7.32 & 10.2 \\
\hline 1584 & 35 & 16 & D & 22.8 & 95.4 & $\frac{3.14}{3.28}$ & 8.6 & 6.2 & 155.7 & 38 & 7.34 & 22.7 \\
\hline 1845 & 38 & 9 & C & 22.6 & 96.2 & $\frac{3.02}{3.28}$ & 8.1 & 4.6 & 152.6 & 37 & 7.42 & 21.1 \\
\hline $2140^{*}$ & 23 & 8 & F & 24.7 & 94.8 & & & & 150.9 & 44 & & \\
\hline $2817^{*}$ & 18 & 4 & C & 25.1 & 94.9 & $\frac{3.90}{2.67}$ & 11.0 & 5.1 & 153.2 & 31 & & 16.8 \\
\hline 3009 & 18 & 7 & $\mathrm{C}$ & 22.9 & 94.8 & $\frac{3.14}{3.35}$ & 8.8 & 6.5 & 148.6 & 27 & & 15.6 \\
\hline $3100^{*}$ & 34 & 6 & C & 27.3 & 87.8 & $\frac{3.65}{2.37}$ & 10.4 & 4.6 & 148.3 & 39 & 7.44 & 17.5 \\
\hline $3713^{*}$ & 42 & 8 & C & 27.4 & 85.0 & $\frac{3.42}{2.01}$ & 10.1 & 3.9 & 152.0 & 45 & & 23.7 \\
\hline
\end{tabular}


TABLE III-Continued

\begin{tabular}{|c|c|c|c|c|c|c|c|c|c|c|c|c|}
\hline Case no. & Age & $\begin{array}{l}\text { Day of } \\
\text { disease }\end{array}$ & $\begin{array}{l}\text { Severity } \\
\text { of case }\end{array}$ & $\begin{array}{c}\mathrm{CO}_{2} \\
\text { content } \\
\text { (1) }\end{array}$ & $\begin{array}{l}\mathrm{Cl} \\
\text { (2) }\end{array}$ & $\begin{array}{l}\text { Alb.' } \\
\text { Glob. }\end{array}$ & $\begin{array}{c}\text { Albumi- } \\
\text { nate } \\
\text { (3) }\end{array}$ & $\begin{array}{c}\text { Globuli- } \\
\text { nate } \\
\text { (4) }\end{array}$ & $\begin{array}{l}\text { Total } \\
\text { base }\end{array}$ & NPN & pH & $\begin{array}{c}\text { Undeter- } \\
\text { mined acid } \\
\text { (total base } \\
\text { minus } \\
1+2+3+4)\end{array}$ \\
\hline 4441 & 18 & 12 & D & $\begin{array}{l}\text { m. eq. } \\
\text { per l. } \\
24.7\end{array}$ & $\begin{array}{l}\text { m.eq. } \\
\text { per l. } \\
88.6\end{array}$ & 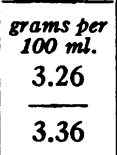 & $\begin{array}{c}\text { m.eq. } \\
\text { per l. } \\
9.0\end{array}$ & $\begin{array}{c}\text { m. eq. } \\
\text { per l. } \\
6.5\end{array}$ & $\begin{array}{l}\text { m.eq. } \\
\text { per } \\
143.2\end{array}$ & 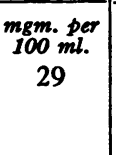 & 7.37 & $\begin{array}{c}\text { m. eq. } \\
14.4\end{array}$ \\
\hline 4749 & 16 & 9 & C & 27.8 & 84.3 & $\frac{3.12}{2.52}$ & 9.2 & 5.0 & 146.0 & 49 & 7.50 & 19.7 \\
\hline 4854 & 18 & 10 & F & 16.4 & 82.3 & $\frac{3.46}{2.44}$ & 9.6 & 4.7 & 140.5 & 124 & 7.37 & 27.5 \\
\hline 4854 & & 15 & & 27.6 & 85.6 & $\frac{2.32}{2.39}$ & 6.7 & 4.7 & 148.9 & 55 & 7.47 & 24.3 \\
\hline 4934 & 35 & 8 & F & 24.9 & 81.9 & $\frac{3.37}{2.66}$ & 9.7 & 5.3 & 144.9 & 27 & 7.47 & 23.1 \\
\hline 5225 & 22 & 8 & E & 22.2 & 91.0 & $\frac{3.38}{2.80}$ & 9.6 & 5.4 & 147.0 & 33 & 7.44 & 18.8 \\
\hline 5225 & & 16 & & 20.8 & 96.0 & $\frac{3.39}{3.41}$ & 9.5 & 6.6 & 148.7 & 31 & 7.40 & 15.8 \\
\hline 5951 & 24 & 11 & E & 30.9 & 97.7 & $\frac{3.20}{4.41}$ & 9.3 & 8.7 & 162.0 & 42 & 7.47 & 15.4 \\
\hline
\end{tabular}

* Patients receiving para-aminobenzoic acid therapy; in these cases the m. eq. of para-aminobenzoic acid were determined and corrected for in the undetermined acids.

Note: The $\mathrm{m}$. eq. of base bound to albumin and globulin was calculated by the following equation (10):

$$
\begin{aligned}
& \text { Albuminate }=0.125\left(\frac{\text { grams alb. }}{\text { liter }}\right)(\mathrm{pH}-5.16) \\
& \text { Globulinate }=0.077\left(\frac{\text { grams glob. }}{\text { liter }}\right)(\mathrm{pH}-4.89)
\end{aligned}
$$

of Egypt. The failure of typhus patients to perspire was observed also by members of the Typhus Commission in moist climates. The salt was not lost in the urine, for the excretion of salt by that route was in relation to the concentration of the chlorides in the serum. When the serum chlorides dropped below normal, the urinary chlorides diminished markedly. The fact that the serum chlorides returned to normal spontaneously in spite of a poor salt intake is added evidence that the salt was not lost by the body, and suggests that the lowered chloride concentration was due to an expansion of the volume of extracellular fluid.

During the early stage of typhus the patients frequently have non-pitting edema. In the late stage of typhus, shortly before defervescence, there is often a fairly marked diuresis. These observations suggest that early in the disease there is an increase in extracellular fluid which would lower the serum chlorides, while later in the disease there is a loss of extracellular fluid and a diuresis resulting in a rise in serum chlorides.

The change in extracellular fluid volume was calculated in all cases where the data permitted. By assuming that the initial extracellular fluid volume was equivalent to 20 per cent of the body weight, change was calculated from the data on the salt balance and the change in the concentration of the serum chlorides. In the majority of these cases there was a loss in extracellular fluid during 


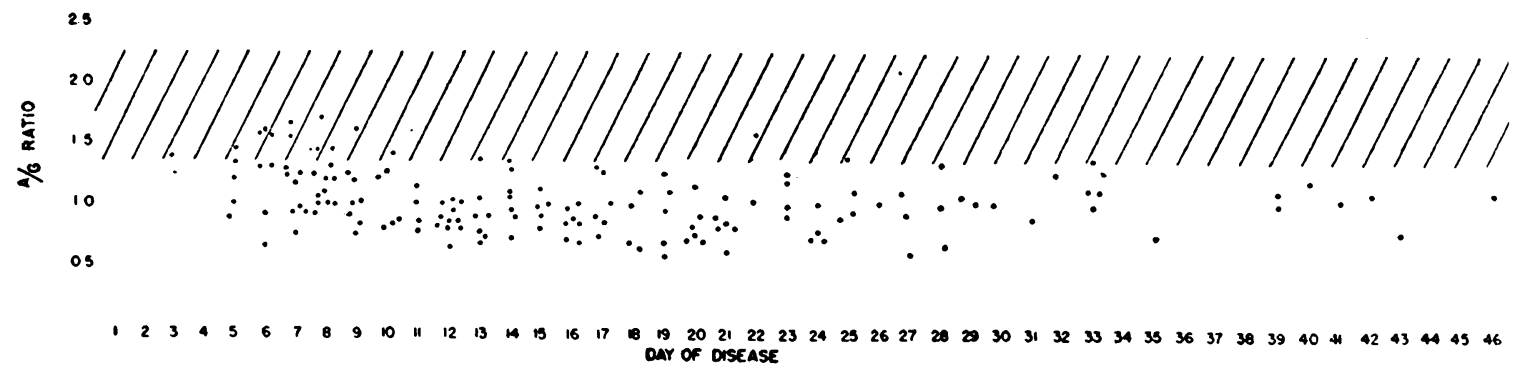

Fig. 2. The Lined Areas Represent the Normal, Range of Values

the period when the serum chlorides rose. Although the change in the calculated volume of the extracellular fluid had a definite bearing on the change of body weight in these patients, the relationship was not close quantitatively.

The raising of the serum chlorides to abnormally high levels by the daily ingestion of 7 to 11 grams of salt occurred in typhus patients with azotemia and renal insufficiency, as well as in typhus patients with apparently normal renal function. This differs from what usually occurs either in the normal individual or in the nephritic. The body weight of these typhus patients frequently could be increased as much as 5 pounds over a period of days by the administration of 7 to 11 grams of salt each day. In one case a slight amount of pitting edema was noted, but in the other cases the salt intake was reduced before this could take place. In view of the effect of large amounts of salt on the serum chlorides, one must be careful not to overload the patient with salt. It would seem unwise to administer to typhus patients of this size more than 6 grams of salt a day without following the serum chloride concentration. A good example of the effect of salt on the patient's body weight is illustrated in Figure 8 .

The increase in undetermined acid anions was as large as one encounters in severe metabolic acidosis. However, it was not reflected in the carbon dioxide content or in the $\mathrm{pH}$ of the serum, as both of these usually were within normal limits. Since the total base and the bicarbonate were within normal limits, the invading acid had apparently replaced chloride and albumin anions. The difference between this electrolyte pattern and the one in diabetic acidosis is shown by the diagrams in Figure 3 ; in typhus, serum reduction of $\left(\mathrm{BHCO}_{3}^{-}\right)$by the abnormal anion $\left(\mathrm{X}^{-}\right)$is prevented by recession of $\left(\mathrm{Cl}^{-}\right)$. Therefore, the administration of ammonium chloride to typhus patients obviously is contraindicated. 

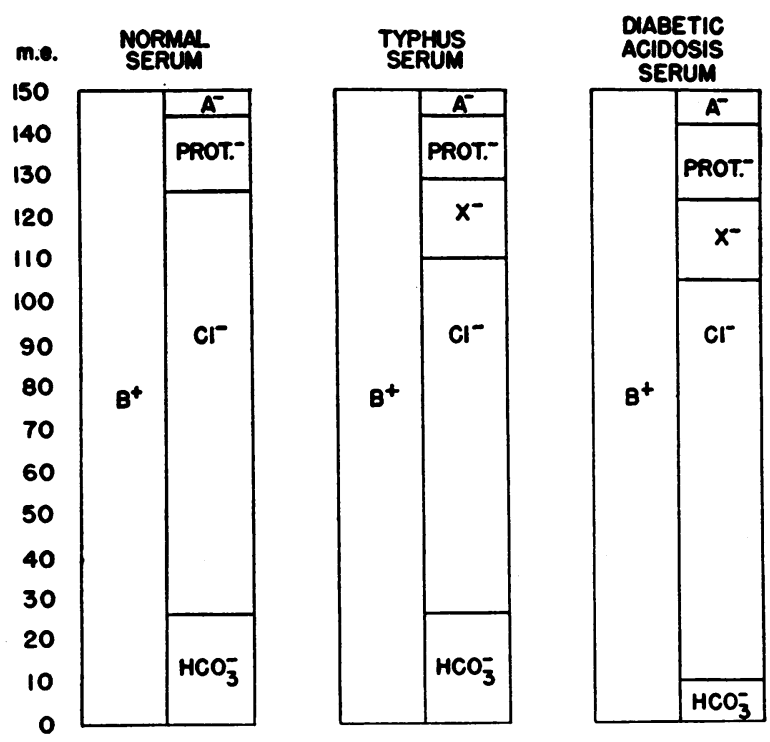

Fig. 3. The Electrolyte Pattern in the Serum of Typhus Patients as Compared with that Seen in the Normal Individual and in the Patient with Diabetic Acidosis

"B +" represents total base. "A -" represents normal undetermined acid including phosphate and sulfate. "X -" represents pathological acids, and "prot -" represents the base bound to protein.

\section{Serum Protein Partition}

Specimens of serum obtained at different times during the disease and convalescence were analyzed for total protein, albumin and globulin. The results showed consistent abnormalities. The least change took place in the total proteins. Most of these were normal throughout the whole course of the disease, but a few were low during the first 2 weeks.

The albumin fraction was subnormal in almost all of the cases. This change was noted as early as the 5th day of disease, and usually persisted for 3 weeks. After that it rose gradually, but in some instances it was low even as late as the 5 th and 6 th weeks. When the albumin was below 2.5 grams per cent, the patients were always edematous.

The globulin fraction was abnormally elevated in most of the cases. This change occurred as early as the 5th day of disease. Throughout the course of the infection the globulins rose steadily. After the 3rd week when the temperature usually was normal they reached a plateau. At this time they were often above 4 grams per cent. This represented a percentage increase from the initial to the final determination of over 40 per cent. If normal protein values had been obtained on these patients before the infection the percentage increase would have been still greater, as the value on the first determination usually was abnormally high.

The albumin-globulin ratio was usually low from the 5th day of disease on. It decreased further, and became reversed in the 2nd and 3rd weeks and it was still low even as late as the 7th week. The results of these studies are shown in Figure 2.

The percentage increase of over 40 per cent in serum globulins within a period of 3 weeks was a striking finding. High values for globulins often existed before the rash appeared or serological diagnostic tests became positive. As high values for serum globulins were seen rarely in conditions which could be confused with typhus, this abnormality helped to support the diagnosis of typhus early in the disease. No clear relation existed between the concentration of the globulins and the titres of the Weil-Felix or complement-fixation tests. It was noted that when the Proteus OX-19 agglutination titre was decreasing, the concentration of globulins frequently was increasing. Moreover, the change in serum globulins often occurred several days before serologic tests were positive. If the increase in globulins represents an increase in protective antibodies, the response occurs at an early stage in the clinical disease.

\section{NITROGEN BALANCE}

Results. Nitrogen balance studies were carried out on 21 patients. These studies covered periods during the acute stage of the disease and the convalescence. An attempt was made to study other patients along these lines, but due to the severity of the disease or to their failure to cooperate, insufficient data were obtained to warrant presenting. The gravely ill typhus patients, as a rule, were unable to tolerate the full quantity of the high protein, high caloric diet.

Of the 21 patients reported, 8 received high protein, high caloric diets, 10 received low protein, low caloric diets, and 3 received a combination of these diets. A summary of the results is shown in Table IV. Individual charts of selected cases are shown in Figures 4 to 8. 


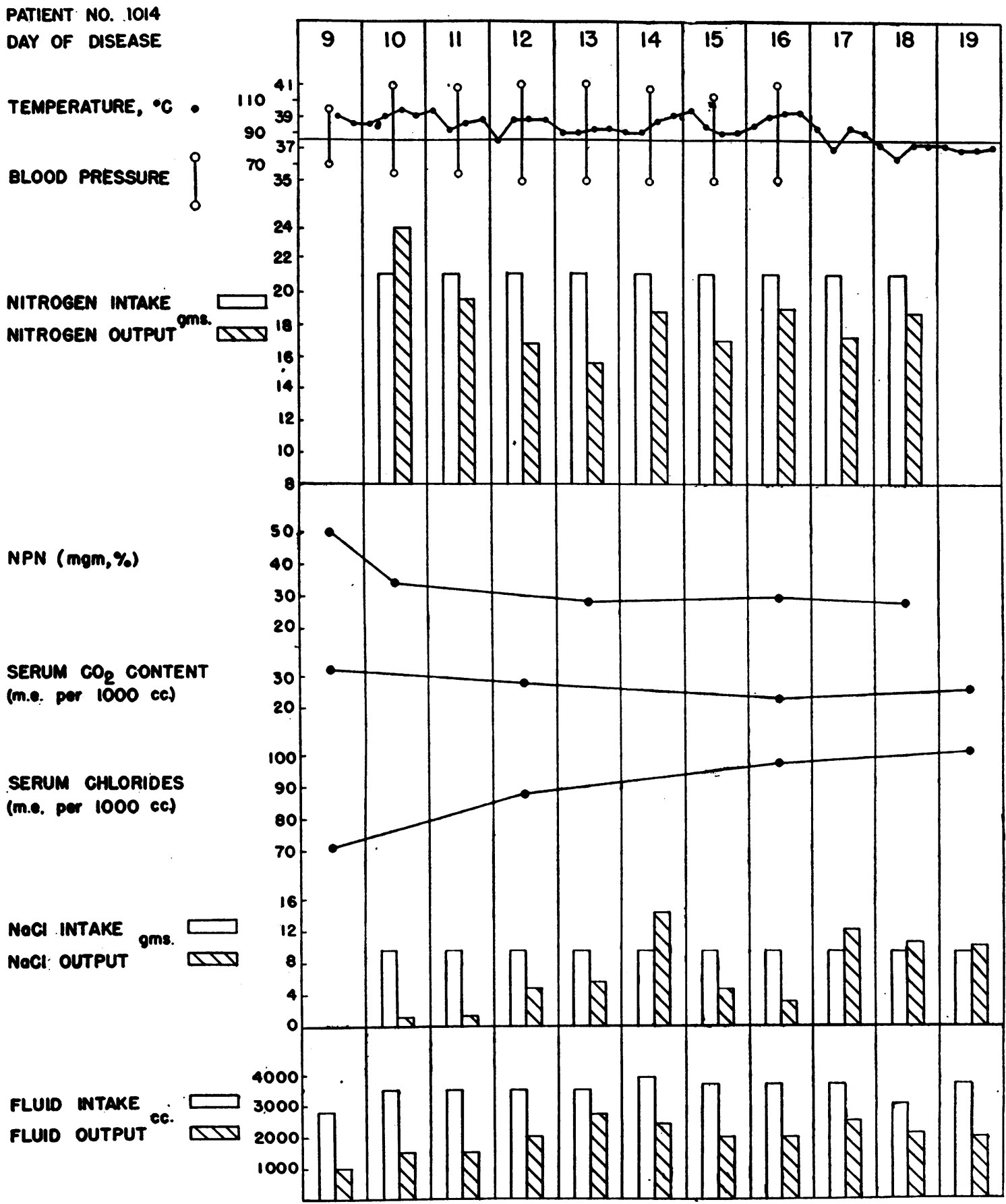

Fig. 4. Patient 1014, a 35-Year Old Man

This patient was admitted to the Commission ward on the 9th day of disease. He was given a daily diet containing 21.2 grams of nitrogen and 3,400 calories. He was acutely ill and febrile until the 18th day, but during this time he was kept in positive nitrogen balance except for one day, and his total nitrogen balance for this whole period was plus 22.4 grams. In convalescence he appeared well nourished. 
TABLE IV

Data on the nitrogen balance during the febrile period in 21 typhus patients

\begin{tabular}{|c|c|c|c|c|c|c|c|c|c|c|c|c|c|c|c|c|}
\hline $\begin{array}{l}\text { Case } \\
\text { no. }\end{array}$ & Age & Height & $\underset{\text { weight }}{\text { Adm. }}$ & $\begin{array}{l}\text { Sur- } \\
\text { face } \\
\text { area }\end{array}$ & $\begin{array}{c}\text { Day } \\
\text { of dis- } \\
\text { ease } \\
\text { diet } \\
\text { started }\end{array}$ & $\begin{array}{l}\text { Days } \\
\text { on } \\
\text { bal- } \\
\text { ance }\end{array}$ & $\begin{array}{c}\text { Average } \\
\text { daily } \\
\text { nitro- } \\
\text { gen } \\
\text { intake }\end{array}$ & $\begin{array}{c}\text { Average } \\
\text { daily } \\
\text { nitro- } \\
\text { gen } \\
\text { output }\end{array}$ & $\begin{array}{c}\text { Total } \\
\text { nitrogen } \\
\text { balance }\end{array}$ & $\begin{array}{c}\text { Aver- } \\
\text { age } \\
\text { daily } \\
\text { salt } \\
\text { intake }\end{array}$ & $\begin{array}{c}\text { Aver- } \\
\text { age } \\
\text { daily } \\
\text { salt } \\
\text { output }\end{array}$ & $\begin{array}{c}\text { Aver- } \\
\text { age } \\
\text { daily } \\
\text { urine } \\
\text { volume }\end{array}$ & $\begin{array}{l}\text { Highest } \\
\text { blood } \\
\text { NPN }\end{array}$ & $\begin{array}{c}\text { Total } \\
\text { change } \\
\text { in } \\
\text { weight }\end{array}$ & $\begin{array}{c}\text { Days } \\
\text { of } \\
\text { fever }\end{array}$ & $\begin{array}{c}\text { Se- } \\
\text { verity } \\
\text { of } \\
\text { case }\end{array}$ \\
\hline & & $c m$. & $\mathrm{kgm}$. & sq. $m$. & & & grams & grams & grams & grams & grams & $m l$. & $\begin{array}{c}\text { mgm. } \\
\text { per } \\
100 \mathrm{ml} .\end{array}$ & kgm. & & \\
\hline 4441 & 18 & 166 & 51.0 & 1.56 & 7 & 14 & 21.2 & 24.5 & -46.2 & 3.0 & 7.5 & 2300 & 41 & -1.8 & 25 & D \\
\hline 3009 & 18 & 162 & 40.0 & 1.38 & 8 & 9 & 18.9 & 16.2 & +24.3 & 7.7 & 6.6 & 1700 & 36 & 0.0 & 16 & $\bar{C}$ \\
\hline 3284 & 25 & 163 & 55.7 & 1.59 & 7 & 10 & 17.9 & 22.0 & -41 . & 7.0 & 10.7 & 200 & 50 & -0.9 & 17 & C \\
\hline 1105 & 32 & 54 & 41.5 & 1.41 & 8 & 8 & 20.3 & 16.8 & +28.0 & 9.5 & 11.7 & 1500 & 31 & 0.0 & 17 & C \\
\hline 1609 & 38 & 178 & 61.7 & 1.76 & 8 & 7 & 18.4 & 19.0 & -4.2 & 9.5 & 6.2 & 2200 & 27 & +0.3 & 15 & C \\
\hline 1174 & 28 & 166 & 54. & 1.60 & 9 & 4 & 21.2 & 15.9 & +21.2 & 8.6 & 8.2 & 1500 & 33 & +0.4 & 12 & B \\
\hline 696 & $\begin{array}{l}20 \\
35\end{array}$ & 155 & 51. & 1.4 & 10 & 5 & 17.4 & 17.0 & +2.0 & 9.5 & 9.6 & 1750 & 35 & -4.5 & 17 & C \\
\hline $\begin{array}{l}1014 \\
1499\end{array}$ & $\begin{array}{l}53 \\
23\end{array}$ & $\begin{array}{l}173 \\
173\end{array}$ & 61.8 & 1.73 & 6 & $\begin{array}{l}8 \\
9\end{array}$ & $\begin{array}{l}21.2 \\
12.8\end{array}$ & $\begin{array}{l}18.4 \\
31.9\end{array}$ & $\begin{array}{r}+22 . \\
-171 .\end{array}$ & $\begin{array}{l}9.5 \\
5.0\end{array}$ & $\begin{array}{l}6 . \\
1 .\end{array}$ & $\begin{array}{l}1900 \\
1800\end{array}$ & $\begin{array}{l}33 \\
96\end{array}$ & -8.9 & $\begin{array}{l}17 \\
17\end{array}$ & $\begin{array}{l}\mathrm{D} \\
\mathrm{D}\end{array}$ \\
\hline 5225 & 22 & & 56.9 & 1.60 & 7 & 10 & 14.0 & 23.0 & -90 . & 2.5 & & 2300 & 41 & -5.7 & 17 & $\mathrm{E}$ \\
\hline 876 & 20 & & 58.5 & 1.68 & 6 & 9 & 11.3 & 24.1 & -115.2 & 3.3 & 5.1 & 1900 & 39 & -5.7 & 14 & C \\
\hline 5383 & 22 & & 65.0 & 1.73 & 7 & 6 & 6.2 & 23.6 & -104.4 & 6.2 & & & & -2.5 & & \\
\hline 777 & 12 & & 35 & 1.16 & 8 & 9 & 4.1 & 12.0 & -71.1 & S. F.t & 0.6 & 1500 & & -2.3 & 14 & C \\
\hline & 35 & & 51. & 1.53 & 8 & 6 & 6.1 & 21.6 & -93.0 & S. F. & 3.3 & 1700 & 63 & -5.9 & 14 & C \\
\hline 1020 & 36 & & & 1.68 & 9 & 0 & 6.1 & 23.8 & -159.3 & S. F. & 1.8 & & 74 & -4.1 & & C \\
\hline 746 & 17 & & 42 & 1.4 & 10 & 5 & 5.9 & 16.2 & -51.5 & S. F. & 1.2 & 1700 & 43 & -4.1 & & C \\
\hline & 35 & & 47.0 & 1.44 & 10 & 6 & 5.0 & 18.7 & -82.2 & S. F. & 2.0 & 1800 & 59 & -1.8 & 15 & D \\
\hline & 42 & & & 1.6 & 7 & 12 & 6.1 & 21.7 & -187.2 & 6.0 & & & 47 & -4.1 & & C \\
\hline & 23 & & & 1.7 & 7 & 10 & 6.1 & 22.6 & -165.0 & 6.0 & & & & -2.3 & & B \\
\hline $4601 *$ & 20 & & 59 & & 7 & 7 & 4.4 & 17.5 & -91 & 5.0 & & & 4 & -1.3 & 1 & B \\
\hline & 27 & & & 1.5 & 8 & 11 & 5.9 & 18.1 & -134.2 & 6.0 & & 1800 & 40 & -3.5 & 20 & C \\
\hline
\end{tabular}

* These patients were receiving para-aminobenzoic acid therapy (8). In these cases the para-aminobenzoic acid was determined in the blood and urine and its nitrogen content was corrected for in the above values.

$\dagger$ Salt-free.

Note: Cases 4441 to 1014 on high protein diet; cases 1499 to 876 on a combination of high and low protein diets; cases 5383 to 4845 on low protein diet.

Note: The average daily salt intake listed here may differ from that listed in Table II because of the difference in time intervals over which the average was calculated.

Data are presented in Table IV showing the nitrogen intake and output, the non-protein nitrogen of the blood, and the weight change, as well as other pertinent observations. The daily fecal nitrogen is not recorded in the table as such, but it is included in the total nitrogen output. It varied from 0.5 to 4 grams daily. As can be seen in Table IV, the patients receiving low protein diets consistently had large nitrogen deficits and lost much weight. When the patients were receiving high protein diets, both the nitrogen deficit and the weight loss were markedly diminished. Five patients on the high protein diet had positive nitrogen balances during both the acute illness and the convalescence. Two patients actually gained weight during the acute illness, but some of this weight was due to increased hydration rather than deposited body fat or protein. The salt intake in these cases undoubtedly had an important influence on this weight gain. An example of this is shown in Figure 8.
The amount of nitrogen in the diet had no definite bearing on the total nitrogen excreted or on the non-protein nitrogen of the blood. Some of the patients receiving the low protein diets excreted more nitrogen than the patients on high protein diets. There was likewise no definite relationship between the occurrence of azotemia and the amount of protein destroyed. The urine output in these cases was between 1 and 3 liters daily. With normal renal function this amount should have been sufficient for the excretion of these excess nitrogenous products and the prevention of azotemia. We consider that patients 1499,967 , 1020 and 1584 had renal insufficiency.

In Table $\mathrm{V}$ the data on the nitrogen balance are presented on 8 patients who received the high protein, high caloric diet. This table is arranged to show the days when the patient was gaining or losing nitrogen. If the nitrogen intake were greater than the total nitrogen output on any day, the values were placed on the positive side of the 


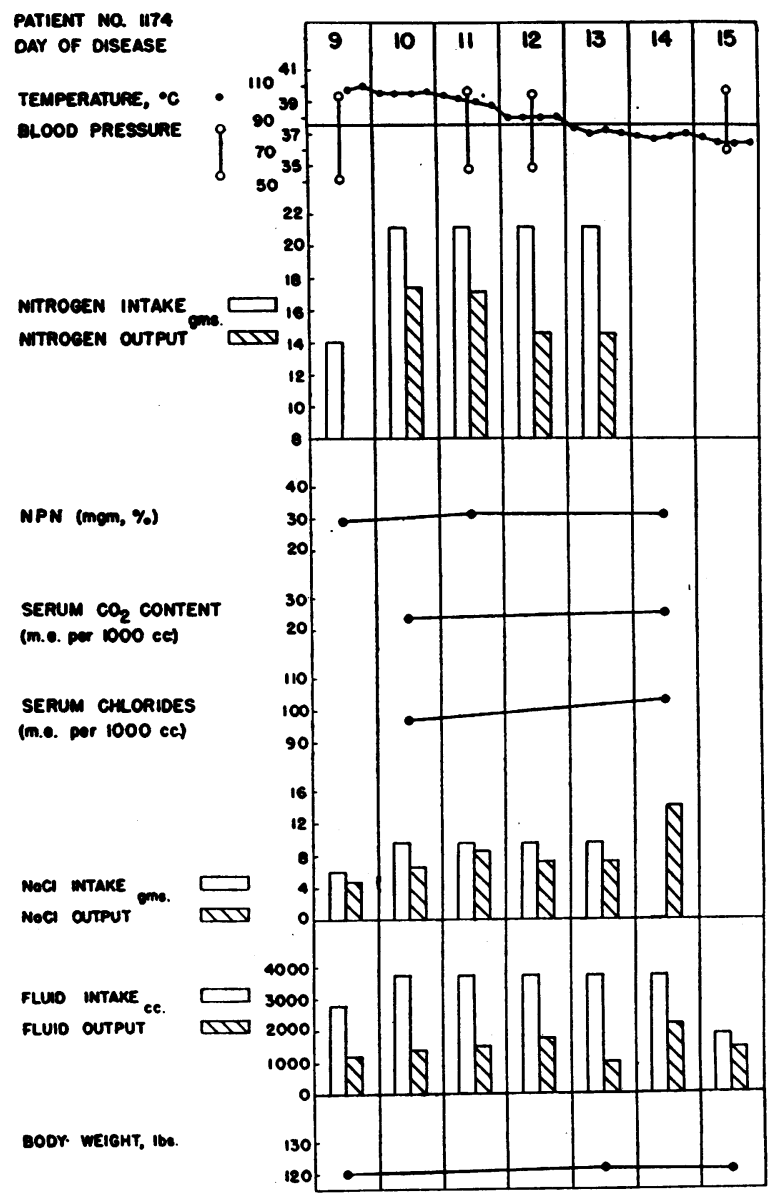

Fig. 5. Patient 1174, a 28-Year Old Man

This patient was admitted to the Commission ward on the 9th day of disease. He was given a daily diet containing 21.2 grams of nitrogen and 3,400 calories. He was acutely ill and febrile until the 13th day, but during this period he was kept in positive nitrogen balance and had a total nitrogen balance of plus 21.2 grams. The patient gained 1 pound during this period but this may have been due to the increased hydration influenced by the salt intake. The sodium chloride balance data are also included in this chart.

table; if the reverse were true, the values were placed on the negative side of the table. The total balance was obtained as follows: Total nitrogen balance $=($ nitrogen intake - nitrogen output $X$ days on positive balance) - (nitrogen intake - nitrogen output $x$ days on negative balance).

The type of diet had no noticeable effect on the changes observed in the serum proteins. The depression of the albumin and the elevation of the globulin occurred as frequently with high protein diets as with low protein diets.
The diet had no apparent effect on the course of the acute illness, but excluding the paraaminobenzoic acid cases, the patients who had received the high protein, high caloric diets appeared in convalescence, in most instances, to be stronger and much better nourished than the others. It appeared that they would be able to return to their work sooner because of this improved state of nutrition.

Comment. Many attempts have been made to prevent or mitigate wastage of nitrogen in acute infectious diseases. The results of such studies showed that in the majority of cases this could not be achieved. Only in chronic cases where there had been previous wasting could positive nitrogen balances frequently be obtained (11).

It has been demonstrated here that a diet high in protein and calories decreased wastage of nitrogen and loss of body weight during the acute phase of typhus. In 5 patients positive nitrogen balances were obtained during a period when the body temperature was around $39^{\circ}$ or $40^{\circ} \mathrm{C}$. Undoubtedly, these patients had large nitrogen deficits in the first week of illness prior to their hospitalization, and it is possible that this may have had some influence on their ability to store nitrogen at a later period. On the other hand, it is a well known fact that the 2 nd week of the clinical disease is the critical period in the course of louseborne typhus. During this week, patients show the greatest number of symptoms and signs of toxicity and central nervous system involvement. The majority of balance studies reported covered the period between the 7th and 14th day of the disease. Therefore, the data were obtained during the period in which these patients were most severely ill, and at this time they probably were destroying more protein than before. Thus, it seems unlikely in these cases than the presumed nitrogen loss during the first week of disease was an important factor in producing the positive nitrogen balance during the 2nd week of disease. The main reason for obtaining positive nitrogen balances in these cases appears to be the very high protein diet.

The 5 patients on whom positive nitrogen balances were obtained were receiving in their diet between 17.4 and 21.2 grams of nitrogen a day, which is the equivalent of between 109 and 132 grams of protein. This would be a high protein 


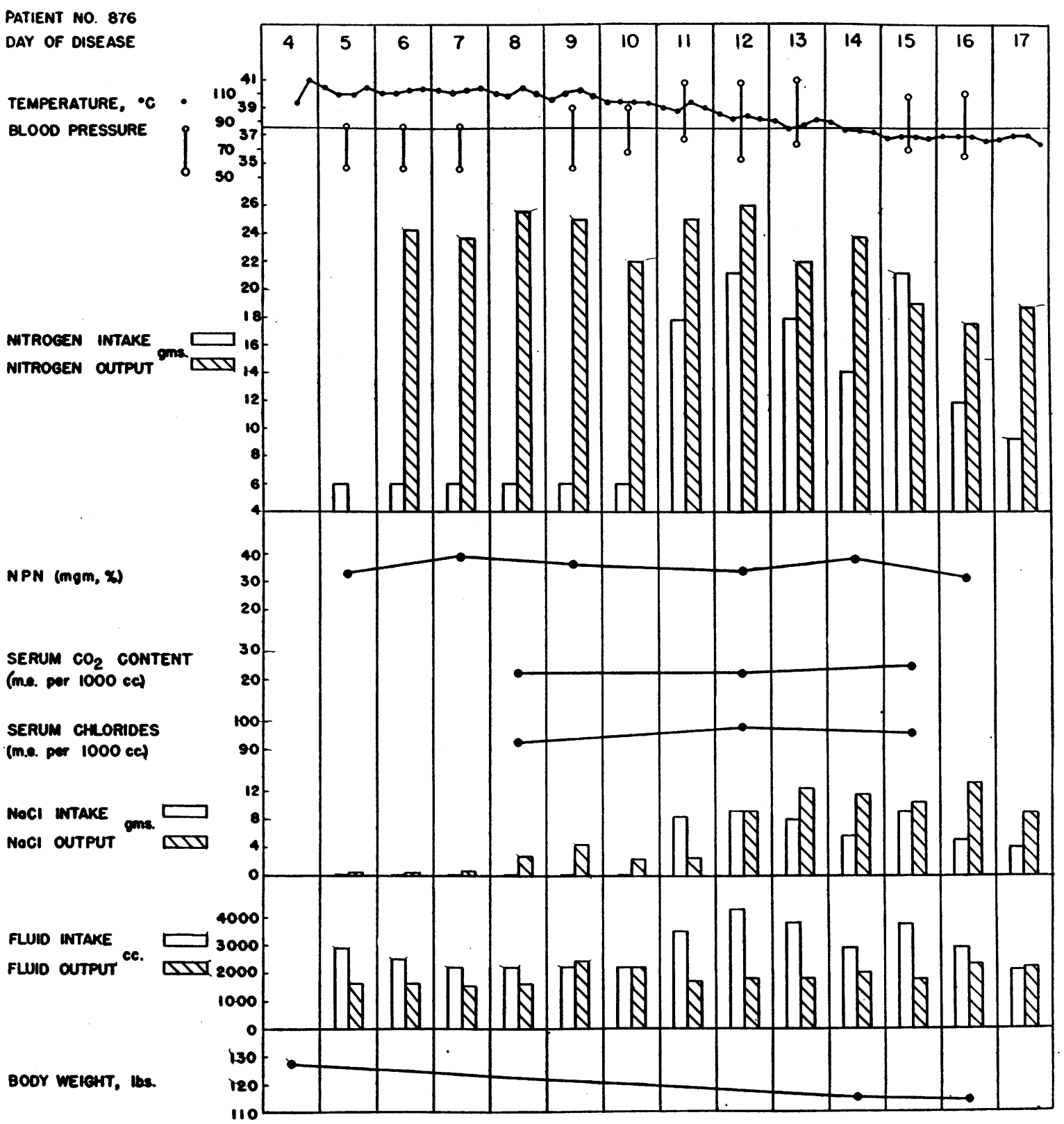

Fig. 6. Patient 876, a 20-Year Old Man

This patient was admitted to the Commission ward on the 4th day of disease. He was given a daily diet containing 6 grams of nitrogen and 1,300 calories. This diet was kept up for 6 days during which time he was severely ill and had a high fever. On this low protein diet he excreted from 22 to 25 grams of nitrogen a day in a urine volume which ranged from 1.5 to 2.5 liters. In spite of the large amount of protein destroyed, the non-protein nitrogen of the blood remained normal. On the 11th day of disease the nitrogen intake was increased to amounts ranging from 14 to 21 grams a day, but there was no appreciable change in the nitrogen output. This patient was continually in nitrogen deficit during the febrile period, and had a total nitrogen balance of minus 115.2 grams. He lost 13 pounds during this time. 


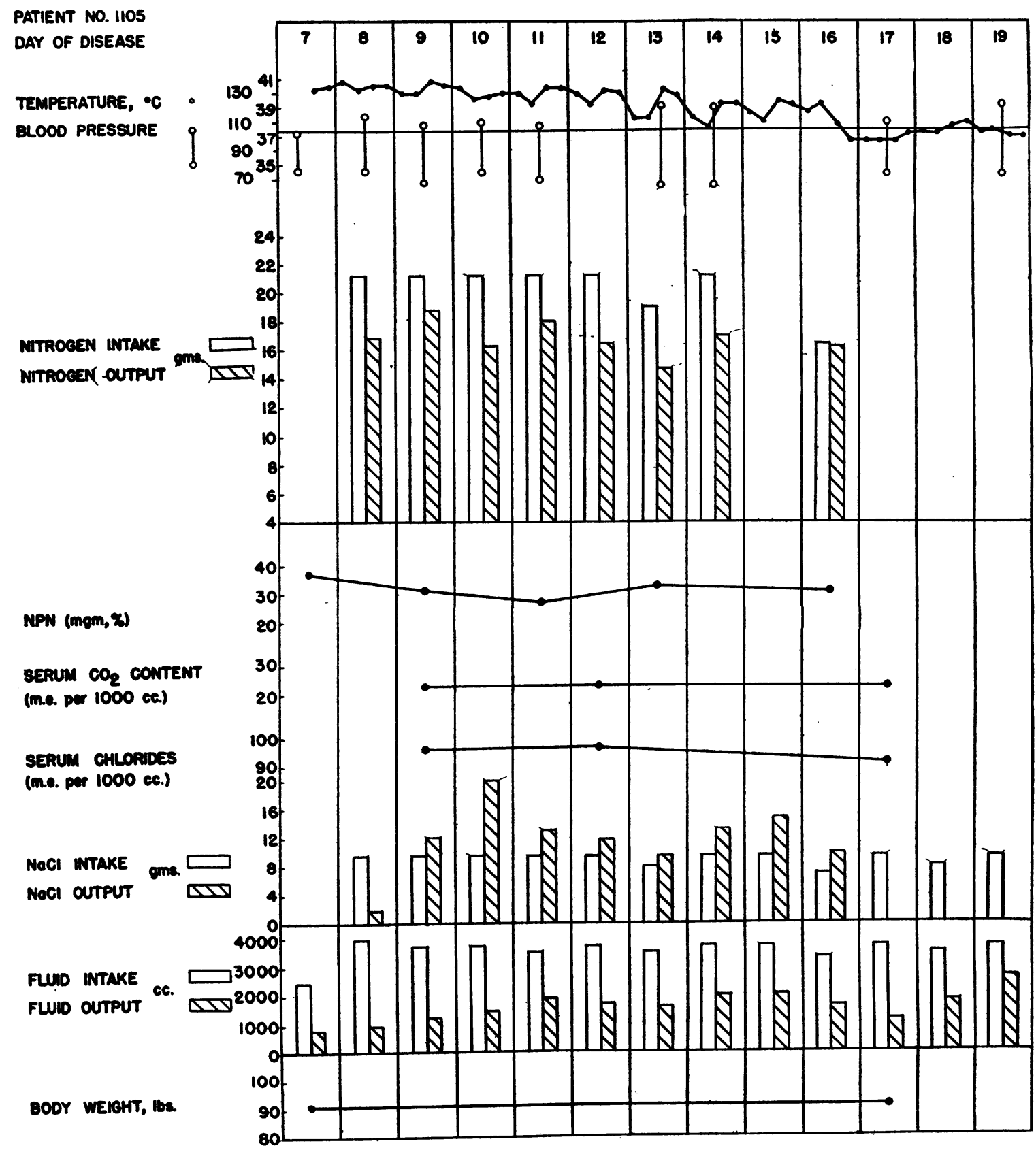

Fig. 7. Patient 1105, a 32-Year Old Man

This patient was admitted to the Commisssion ward on the 7th day of disease. He was given a daily diet containing 21.2 grams of nitrogen and 3,400 calories. He was severely ill and remained febrile until the 17 th day. During this period he was in positive nitrogen balance, and had a total nitrogen balance of plus 28 grams of nitrogen. 
TABLE V

Data on the nitrogen balance during the febrile period in 8 typhus patients on high protein diets

\begin{tabular}{|c|c|c|c|c|c|c|c|c|c|c|c|c|c|c|c|c|}
\hline \multirow[b]{2}{*}{$\begin{array}{l}\text { Case } \\
\text { no. }\end{array}$} & \multirow[b]{2}{*}{ Age } & \multirow[b]{2}{*}{$\underset{\text { weight }}{\text { Adm. }}$} & \multirow{2}{*}{$\begin{array}{l}\text { Day of } \\
\text { disease } \\
\text { diet } \\
\text { started }\end{array}$} & \multicolumn{4}{|c|}{ Negative nitrogen balance } & \multicolumn{4}{|c|}{ Positive nitrogen balance } & \multirow{2}{*}{$\begin{array}{c}\text { Total } \\
\text { nitro- } \\
\text { gen } \\
\text { bal- } \\
\text { ance }\end{array}$} & \multirow{2}{*}{$\begin{array}{l}\text { Aver- } \\
\text { age so- } \\
\text { dium } \\
\text { chlor- } \\
\text { ide in- } \\
\text { take* }\end{array}$} & \multirow[b]{2}{*}{$\begin{array}{c}\text { Total } \\
\text { weight } \\
\text { change }\end{array}$} & \multirow{2}{*}{$\begin{array}{c}\text { Days } \\
\text { of } \\
\text { fever }\end{array} \mid$} & \multirow{2}{*}{$\begin{array}{c}\text { Se- } \\
\text { verity } \\
\text { of } \\
\text { case }\end{array}$} \\
\hline & & & & $\begin{array}{c}\text { Average } \\
\text { daily } \\
\text { nitro- } \\
\text { gen } \\
\text { intake }\end{array}$ & $\begin{array}{c}\text { Average } \\
\text { daily } \\
\text { nitro- } \\
\text { gen } \\
\text { output }\end{array}$ & $\begin{array}{c}\text { No. } \\
\text { of } \\
\text { days }\end{array}$ & $\begin{array}{c}\text { Average } \\
\text { daily } \\
\text { nitro- } \\
\text { gen } \\
\text { loss }\end{array}$ & $\begin{array}{c}\text { Average } \\
\text { daily } \\
\text { nitro- } \\
\text { gen } \\
\text { intake }\end{array}$ & $\begin{array}{c}\text { Average } \\
\text { daily } \\
\text { nitro- } \\
\text { gen } \\
\text { output }\end{array}$ & $\begin{array}{c}\text { No. } \\
\text { of } \\
\text { days }\end{array}$ & $\begin{array}{c}\text { Average } \\
\text { daily } \\
\text { nitro- } \\
\text { gen } \\
\text { gain }\end{array}$ & & & & & \\
\hline & & $\mathrm{kgm}$. & & grams & grams & & grams & grams & grams & & grams & grams & $\begin{array}{l}\underset{\text { per day }}{\operatorname{grams}} \\
\text { per }\end{array}$ & kgm. & & \\
\hline $\begin{array}{r}4441 \\
3009 \\
3284 \\
1105 \\
1609 \\
1174 \\
1014 \\
696\end{array}$ & $\begin{array}{l}18 \\
18 \\
25 \\
32 \\
38 \\
28 \\
35 \\
20\end{array}$ & $\begin{array}{l}51.0 \\
40.0 \\
55.7 \\
41.5 \\
61.7 \\
54.5 \\
\\
51.5\end{array}$ & $\begin{array}{r}7 \\
8 \\
7 \\
8 \\
8 \\
9 \\
10 \\
10\end{array}$ & $\begin{array}{l}21.2 \\
18.9 \\
17.7 \\
17.1\end{array}$ & $\begin{array}{l}26.8 \\
20.2 \\
23.1 \\
23.5\end{array}$ & $\begin{array}{r}10 \\
1 \\
8 \\
2\end{array}$ & $\begin{array}{l}5.6 \\
1.3 \\
5.4 \\
6.4\end{array}$ & $\begin{array}{l}21.5 \\
18.9 \\
18.9 \\
20.3 \\
18.9 \\
21.2 \\
21.2 \\
21.2\end{array}$ & $\begin{array}{l}19.1 \\
15.7 \\
17.7 \\
16.8 \\
17.2 \\
15.9 \\
17.6 \\
17.1\end{array}$ & $\begin{array}{l}4 \\
8 \\
2 \\
8 \\
5 \\
4 \\
7 \\
1\end{array}$ & $\begin{array}{l}2.4 \\
3.2 \\
1.2 \\
3.5 \\
1.7 \\
5.3 \\
3.6 \\
4.1\end{array}$ & $\begin{array}{r}-46.4 \\
+24.3 \\
-40.8 \\
+28.0 \\
-4.3 \\
+21.2 \\
+22.4 \\
+2.1\end{array}$ & $\begin{array}{l}3.0 \\
7.7 \\
7.0 \\
9.5 \\
9.5 \\
8.6 \\
9.5 \\
9.5\end{array}$ & $\begin{array}{r}-1.8 \\
0.0 \\
-0.9 \\
0.0 \\
+0.3 \\
+0.4 \\
-4.5\end{array}$ & $\begin{array}{l}25 \\
16 \\
17 \\
17 \\
15 \\
12 \\
17 \\
17\end{array}$ & $\begin{array}{l}\text { D } \\
\text { C } \\
\text { C } \\
\text { C } \\
\text { C } \\
\text { B } \\
\text { D } \\
\text { C }\end{array}$ \\
\hline
\end{tabular}

* The average daily salt intake listed here may differ from that listed in Table II because of the difference in time intervals over which the average was calculated.

diet for the average American man, but when one considers the size of these Egyptian patients, it amounts to a tremendous protein intake. Patients $3009,1105,1174$ and 696 weighed, on admission $40,41.5,54.5$ and $51.5 \mathrm{kgm}$., respectively, and their protein intakes were 2.9, 3.1, 2.4 and 2.1 grams per kgm. of body weight per day. Patient 1014 was not weighed on admission, but his weight on discharge was $55.5 \mathrm{kgm}$. His protein intake was 2.4 grams per $\mathrm{kgm}$. of body weight per day. If patient 3009 had weighed as much as the average American man, i.e., $70 \mathrm{kgm}$., and had received the same protein intake per $\mathrm{kgm}$. of body weight, he would have received the huge quantity of 203 grams of protein per day.

The diet used in this study was composed of such foods as were available, and often there was not much choice. To many of the patients the diet was bulky and monotonous, and occasionally it contributed to nausea and diarrhea. With more foods from which to choose, smaller and more appetizing portions could be made up which would still be high in proteins and calories. On such a diet many typhus patients should ingest sufficient food to mitigate the great loss of body weight which occurs in this disease.

The outstanding feature of these studies of nitrogen balance was the very large and remarkably regular extent of protein catabolism regardless of intake. The average for nitrogen output (Table IV) was 20 grams per day which defines the consumption of 125 grams of protein. This is 3 to 4 times the minimal protein intake requirement under normal circumstances. However, since protein consumption is not found to be increased by intake, it can be covered provided the patient can accept food in sufficient quantity. This was demonstrated by the positive nitrogen balance obtained in $\mathbf{5}$ of the patients studied.

\section{SUPPORTIVE PROGRAM}

From these studies as well as our other observations in typhus, certain supportive measures are suggested for the rational management of the diet, electrolytes and fluid balance in the typhus patient.

(1) A liquid diet high in protein and calories should be administered. With diligent nursing the average patient will ingest at least 90 grams of protein and 2,500 calories a day. If the patient is too ill to take the diet, Amigen ${ }^{4}$ may be given intravenously.

(2) The routine administration of large amounts of sodium chloride without determining the serum chlorides should be avoided. By including in the diet or in the parenteral fluids 4 to 6 grams of sodium chloride a day, the serum chlorides should be kept within normal limits and a good state of hydration achieved. Usually, the fluid intake should be maintained between 3 and 4 liters daily.

(3) The urine output should be at least 1 liter a day, and preferably 1.5 liters. A marked drop in the urine output is an ominous sign, particu-

4 Casein hydrolysate manufactured by Mead Johnson and Company. 


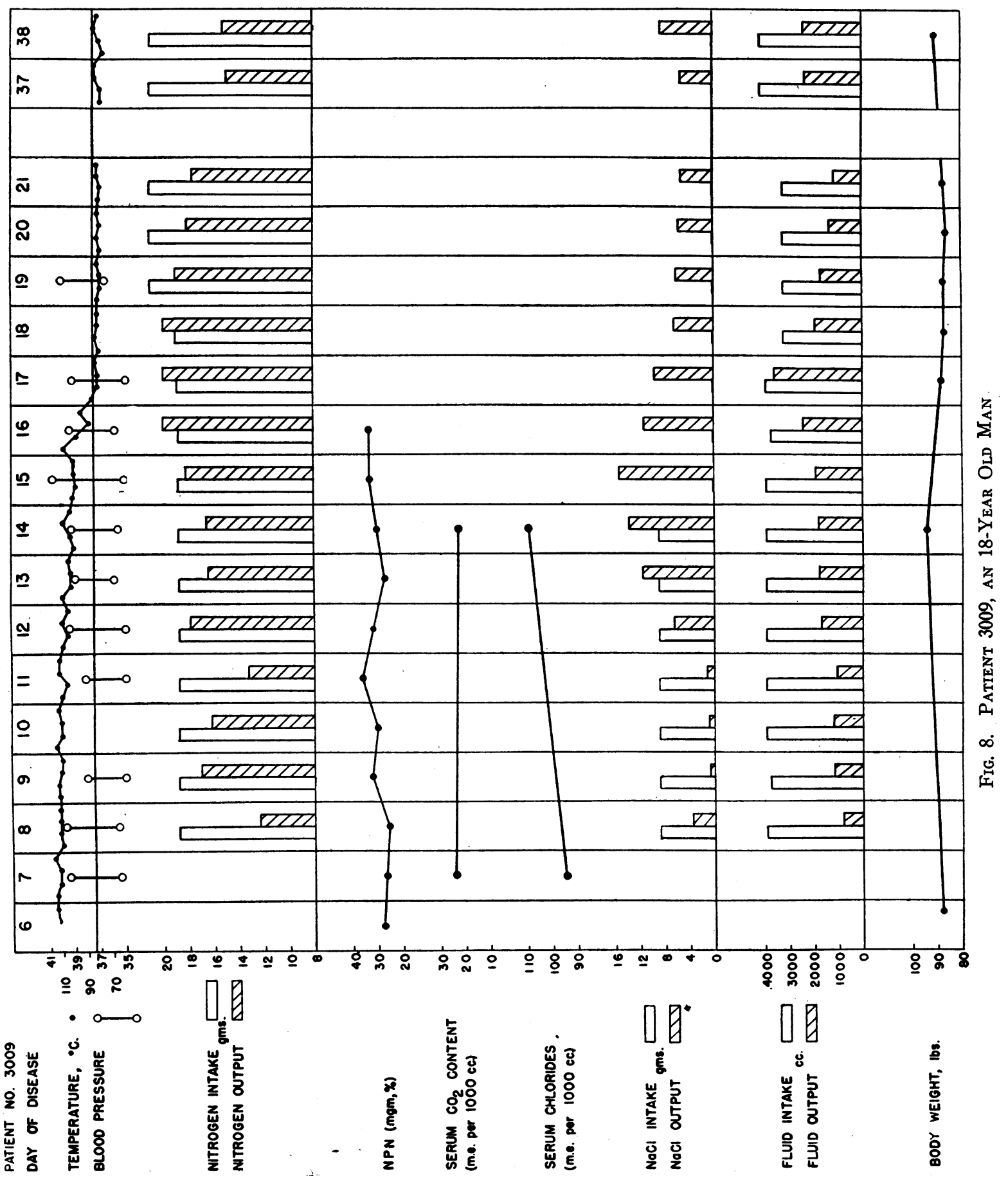


larly if it is associated with a fall in the arterial blood pressure (4): In such instances plasma or blood transfusions are required urgently.

(4) In cases of shock or impending shock, plasma or blood transfusions are indicated. The effect of plasma or blood transfusions on hypoalbuminemia is transient. In order to produce any significant change, very large amounts of plasma over a period of days would be required.

(5) Acid salts such as ammonium chloride, are obviously contraindicated because of the increase in undetermined acids in the blood.

\section{CONCLUSFONS}

1. A study of the electrolyte pattern of the serum revealed that early in the disease the chlorides were low in 62 per cent of the cases, but with few exceptions the carbon dioxide content was normal. The $\mathrm{pH}$ was normal in all of the patients except one who had renal failure and acidosis. The total base was normal in all of the cases studied except one. In all instances the undetermined acid anions were increased, and in the majority of cases they were as great as is encountered in severe metabolic acidosis.

2. The total serum proteins were normal in approximately 75 per cent of the patients, but the majority showed a depression of the albumin fraction and a very striking elevation of the globulin fraction. The increase in globulins represented a percentage increase of over 40 per cent in the average case.

3. There was no relationship between nitrogen output and intake or between protein destruction and azotemia. A high protein, high caloric diet decreased nitrogen wastage and loss of body weight during the acute phase of typhus. Positive nitrogen balances were obtained in $\mathbf{5}$ cases.

\section{ACKNOWLEDGMENTS}

To the officials of the Egyptian Ministry of Public Health who facilitated the studies of the United States of America Typhus Commission in Egypt, the authors wish to express their appreciation for the generous cooperation they received.

To the Director of the Cairo Fever Hospital, Dr. M. A. B. Demerdash Bey, who made possible the establishment of the United States of America Typhus Commission ward and laboratories in his institution, the authors express their sincere gratitude for his constant interest and cooperation in these studies.

The authors are grateful to Dr. A. Baird Hastings, Dr. John P. Peters, Dr. James L. Gamble and Miss Pauline M. Hald whose advice was extremely helpful. It is also a pleasure to acknowledge the invaluable technical assistance of Ph.M. 1/c Peterson, Ph.M. 2/c Reynolds, Ph.M. 3/c Scarborough, Sergeants Stephens and Friedberg.

\section{BIBLIOGRAPHY}

1. Murchison, C., Treatise on Continued Fevers of Great Britain, 1862, Parker, Son and Bourn, London.

2. Aschenbrenner, R., Uber uremische Zustande beim Fleckfieber. Klin. Wchnschr., 1944, 23, 8.

3 .Woodward, T. E., and Bland, E. F., Clinical observations in typhus fever with special reference to the cardiovascular system. J. A. M. A., 1944, 126, 287.

4. Yeomans, A., Snyder, J. C., Murray, E. S., Ecke, R. S., and Zarafonetis, C. J. D., Azotemia in typhus fever. Ann. Int. Med., 1945, 22, No. 5, 711.

5. Peters, J. P., and Van Slyke, D. D., Quantitative Clinical Chemistry, 1935, Vol. I, Williams and Wilkins Co., Baltimore, Md.

6. Julliard, J., and Henaff, M., Troubles du metabolisme hydro-chlorure au cours des typhus epidemique et murin. Rev. du Serv. de San. Mil., 1939, 110, 197.

7. Bayne-Jones, S., The United States of America Typhus Commission, Army Med. Bull., 1943, No. $68,4$.

8. Yeomans, A., Snyder, J. C., Murray, E. S., Zarafonetis, C. J. D., and Ecke, R. S., The therapeutic effect of para-aminobenzoic acid in louse-borne typhus fever. J. A. M. A., 1944, 126, 349.

9. Peters, J. P., and Van Slyke, D. D., Quantitative Clinical Chemistry, 1942, Vol. II, Williams and Wilkins Co., Baltimore, Md.

10. Van Slyke, D. D., Hastings, A. B., Hiller, A., and Sendroy, J., Jr., XIV. The amounts of alkali bound by serum albumin and globulin. J. Biol. Chem., 1928, 79, 769.

11. Peters, J. P., Symposium on physiological aspects of convalescence and rehabilitation. Problems of nitrogen metabolism. Fed. Proc., 1944, 3, 197.

\section{Explanation to Fig. 8}

This patient was admitted to the Commission ward on the 6 th day of disease. He was given a daily diet containing 19 grams of nitrogen and 3,200 calories. He was acutely ill and febrile until the 17th day, but during this time he was kept in positive nitrogen balance except for 2 days, and his total nitrogen balance was plus 24.3 grams. The salt intake in this patient had a very noticeable effect on his body weight. On a salt intake of 9.5 grams a day the serum chlorides rose from 95 m.eq. per liter to $104 \mathrm{~m}$.eq., and associated with this the body weight increased from 88 to 94 pounds! At this point all added salt was removed from the diet and in 3 days the body weight decreased to 88 pounds where it remained until late in convalescence. 